[Stevens, K. (1996). The Technological Challenge to the Notion of Rurality in New Zealand Education - Repositioning the Small School. New Zealand Annual Review of Education, 5, 93-102]

\section{The Technological Challenge to the Notion of Rurality in New Zealand Education - Repositioning the Small School}

\author{
KEN STEVENS
}

\section{Abstract:}

Small rural schools in New Zealand are in the forefront of changes in the application of information and communication technologies to teaching and learning. The emergence of rural school electronic networks is an important step towards the development of virtual classes in New Zealand, requiring new ways of organising teaching and learning. It is particularly appropriate to reconsider the pedagogy of the one- and two-teacher school in relation to the emerging virtual class. These small schools could have a new role in the information age and should, accordingly, be repositioned within the national education system.

$\mathrm{T}$ he geographic isolation of the small rural school in many developed countries is changing (Cross and Frankcombe, 1994; Kynaslahti and Salminen, 1995; Oliver and Reeves, 1993; Stevens, 1993a, 1993b, 1994; Tiffin and Rajasingham, 1995) as new information and communication technologies are applied to the delivery of education at regional, national and global levels. In New Zealand the recent proliferation of regional audiographic networks linking small schools with one another, as well as with selected large urban institutions (including polytechnics), indicates a significant change in the organisation of education in rural New Zealand. The now established position of audio-conferencing in rural schools, the possibilities of video-conferencing that are being considered by some communities, and new developments in the delivery of education to rural learners through television by the New Zealand Correspondence
School, provide geographically isolated teachers with an increasingly diverse range of technologies from which to choose.

The new technologies for the delivery of education in rural New Zealand are making possible new ways of teaching and learning as schools "interface" with one another, while their application through the electronic networking of small schools encourages collaborative management. As these technologies combine and are applied to the delivery of education to those New Zealanders who live beyond the main centres of population, the significance of school size and location is reduced, challenging the very notion of rural education.

\section{The Technological Challenge to the Notion of Rurality in New} Zealand Education

The emergence of regional school networks is a major step in the development of "virtual classes" in New Zealand and the beginning of a new paradigm for the delivery of education. The technological challenge to the notion of rurality in New Zealand presents three issues: the move from regional to national networks; tele-teaching and telelearning; and, with the emergence of virtual classes, that of redefining the school itself.

\section{From regional to national school networks}

By late 1995 several regional school networks have been developed, collectively delivering education to considerable areas of the North and South Islands of New Zealand. In the South Island, the former Casatech network has been renamed Cantatech and expanded from six to ten member schools. A new network has been created linking small schools between Picton and Collingwood, appropriately called "The Top of the South Island Technology Project" (Tositech), while in the North Island a network of schools has been established in the Kapiti-Horowhenua area. Yet another network in the North-East Coast, centred on Ruatoria, links several small schools which serve predominantly Maori communities. At present each of these networks is regional in scope, but the beginnings of inter-network collaboration are evident. The Tositech network provides instruction in agriculture to schools linked through the Cantatech network, whilst graphics is taught from one Cantatech site to schools linked by Tositech. A further development in extending networking beyond a particular region is the linking of small East Coast schools to the Waiariki Polytechnic in Rotorua.

The development of networking provides students with access to wider curriculum opportunities at a time when many small schools are 
losing teachers because of budget cuts. Few small schools can do more than offer a very basic curriculum from their own teaching resources, but through collaboration with one another, this problem can be largely overcome. Those which participate in networking can now utilise teachers from other places to extend their curriculum. During 1995, a growing number of small schools have come to interface with one another to form virtual classes, requiring new ways of organising teaching, learning, and inter-institutional management.

At the present time most of the participants in the inter-school classes made possible by the networks are senior students and, according to their teachers, can often work independently for part of the school day. At present it is not known whether younger, unmotivated and teacher-dependent students could participate successfully in networked classes.

The future of the burgeoning rural school networks is dependent on their ability to attract and retain staff who support inter-institutional teaching and learning. At present, networked rural schools all have to provide their own internal training in the use of audiographic technology, although there is some assistance available from the Christchurch College of Education (Mander, 1993, 1994; Telecom New Zealand, 1992). It is possible that regional school networks will in time become national in scope. Beyond that, as New Zealand schools develop links with teachers and learners in other countries, the issue of varying time zones will have to be considered.

\section{Tele-teaching in small networked schools}

Electronic networking of classes in a growing number of schools in rural New Zealand is creating new demands on both teachers and learners. There is little in the academic or professional literature to provide guidance in tele-teaching or tele-learning at the present time. As teachers and learners collaborate to form electronic classrooms, the pedagogy of the very smallest schools (those with one teacher and fewer than twenty students, ranging in age from new entrants to about standard four), could provide a useful organisational model. Many of these schools are in the most geographically isolated areas of the country, and are linked for audiographic teaching at a regional level.

The ways in which teaching and learning have traditionally been organised in the very smallest schools provide insights into the pedagogy other teachers have to consider when adapting new information and communication technologies to their classes. The teacher in the one-teacher school has traditionally had to manage a diverse range of learning activities simultaneously, while at the same time ensuring that all students receive personal attention. This is precisely the task of the tele-teacher in networked rural schools in New Zealand.

Teachers in the very smallest schools have to encourage their students to undertake a considerable amount of independent learning during a typical school day. Sometimes their needs may be met by peer tutoring, by having learners of differing ages and abilities work in pairs. At other times, some students may need to work independently, while the teacher is instructing others individually or in small groups in another part of a single room school. This is a complex learning environment which requires considerable organisational skills if all learners are to be adequately taught. The advantage of audiographic technologies is that they allow some of the learners in such a class to join classes in other schools for part of the school day, without actually leaving their own classroom. With the introduction of audio-conferencing, the one-teacher school will sometimes be the source of lessons for learners in other places, and at other times of the day, will be in receipt of such lessons. Like the teacher in a one-teacher school, the tele-teacher provides students with a balance of individual learning programmes, possible from a range of other schools, as well as individual attention. But unlike the teacher in the one-teacher school, the tele-teacher cannot see his or her students while the lesson is in progress.

Electronic classes make complex demands on teachers. Because audiographic teachers instruct learners they cannot see, the use they make of their voices is quite crucial in the teaching-learning relationship. Long-term planning is essential, too, so that all students are aware of the contribution of each audiographic lesson to their total course of study. The audiographic teacher is largely dependent on colleagues in linked schools to maintain classroom discipline while the lesson is in progress. Audiographic teaching can thus become expensive in teacher time if learners require supervision on all linked sites.

The audiographic teacher is required to make a range of judgements for his or her learners. When is it appropriate for an individual learner to be connected on-line to another school, and when is it more appropriate for students to be taught face-to-face by the teacher? As electronic networks proliferate and, in particular, as schools consider the possibilities of the Internet for access to learning opportunities, it has to be asked which electronically-mediated classes are most appropriate for particular students at particular stages of their learning? What protocols should be developed between teachers in networked classes? When is 
it appropriate to have whole-class teaching? How can educational materials prepared for presentation in a traditional class be adapted to tele-teaching?

Tele-teaching provides learners in rural New Zealand with increased access to courses that would not be available to them in the traditional one-teacher school or the area school. As the Internet is developed, it will become increasingly possible for learners within a single classroom to join classes in an almost unlimited range of other places, simultaneously. The role of the teacher can be expected to change from one emphasising direct, face-to-face instruction to one mediating access to learning from a variety of places, for at least part of the school day.

\section{Tele-learning in small networked schools}

Students in small schools report that audiographic learning makes particular demands on them (Stevens, 1995). In an audiographic class, students cannot see the teacher's body language. They report that they are often unsure of when they will next be asked a question or required to demonstrate their knowledge (or lack of knowledge!) on-line, by a teacher who is represented to them largely as a voice. Many students also reported that they found it necessary to prepare very carefully for their on-line sessions, and needed to concentrate very closely on the lesson if they were to make progress, or at the very least, avoid embarrassment in the presence of their electronic classmates.

Learning in audiographic rural classrooms at the present time is largely dependent for its success on independent learners, many of whom have had previous experience as students of the New Zealand Correspondence School. Discipline has therefore not been a major consideration in networked classes in the initial years of operation. The test of the wider effectiveness of tele-learning in rural schools will come when less motivated, or less academically-able students are expected to participate in electronically networked classes with minimum supervision.

The relationship between the tele-learner and his or her teacher located in another school becomes, increasingly, one of consultation about learning needs. While tele-teaching requires a high degree of long-term planning by teachers, it also requires tele-learners to be able to plan their own learning within this same long-term context. The tele-learner has to adapt to the teaching styles of a variety of teachers who are located in several different schools, just as the teacher has to adjust to teaching students he or she does not know personally and cannot see while a lesson is in progress. To participate effectively in tele-classes, the learner has to be able to use a computer, have some facility with a keyboard, and be able to use a small range of technologies such as multi-point microphones, scanners and facsimile machines. The tele-learner may have to be prepared sometimes to work outside normal school hours, depending on the scheduling of classes from other places (particularly if these are polytechnics). To be effective tele-learners, students should be encouraged to keep careful records of their learning progress during on-line classes, and report to the teacher any difficulties that arise. Tele-learners have to be able to ask questions in the telepresence of other students (who are not necessarily known to them), to be able to participate fully. But they also continue to experience the intimacy of their small schools, while participating to an increasing extent in electronically-mediated classes from other places.

The development of virtual classes - redefining the school in New Zealand Virtual classes are made possible through linking information and communication technologies to enable teachers and learners to interact, regardless of where they are located. According to Tiffin and Rajasingham (1995, p. 6):

A classroom is a communication system that makes it possible for a group of people to come together to talk about something they want to learn, and to look at pictures and diagrams and text that help them understand. In a conventional classroom this is made possible by the walls which provide protection from outside noise and interference so that everybody inside the classroom can hear and see one another and can also see, on a whiteboard or blackboard, words, diagrams and pictures about what is being learned. The question is, can information technology provide an alternative communications system for learning that is at least as effective?

The idea of a virtual class is that everybody can talk and be heard and be identified and everybody can see the same words, diagrams and pictures, at the same time. This calls for the use of telecommunications and computers. At its simplest this can be done using two conventional telephone lines at each site, one to link telephones and one to link computers. One line is for sound and one is for pictures which can be generated on the video display unit (VDU) of a computer. To link more than two sites a tele-conferencing bridging system is also needed. Teleconferencing bridges can be linked to other tele-conferencing 
bridges and theoretically there is no limit to the number of places that can be linked, or to where these places are.

In rural areas, virtual classes are steadily taking shape as schools join audiographic networks by linking themselves to each other electronically. The initial stage of the virtual class, as currently being developed, largely eliminates the significance of both school size and location. A growing number of small schools can access a wide range of options for their students by, in effect, becoming part of other institutions. The virtual class that is beginning to take shape is characterised, first, by its regional rather than its national nature, and second, by the lack of any national co-ordination. Many small rural schools in new Zealand are now semi-autonomous rather than autonomous institutions. Their academic and administrative structures have been integrated with those of other semi-autonomous institutions in other places. They have become teaching and learning sites within large, electronically-mediated virtual classes. Many teachers appointed to rural schools spend increasing amounts of time teaching to geographically distant sites within these virtual classes. Many young New Zealanders who attend geographically isolated schools are able to participate in lessons generated from multiple locations. The notion of a school as a closed, autonomous institution is becoming obsolete.

\section{Repositioning the small school}

The small rural school has attracted a great deal of controversy in New Zealand over the past two years (Middleton, 1996) and has become a focus of political attention (Stevens, 1995). It could be said that such schools are being repositioned, as they take their place within the information society. In 1995, the most obvious feature of the traditional small school that has been technologically-enhanced to link with other institutions for teaching and learning is that it has become, in effect, a large school - a site within an electronically-networked education delivery system that is rapidly growing and changing shape. The proliferation of rural school networks is repositioning the small school within other schools, urban as well as rural, and also within some New Zealand polytechnics. In spite of this, many small schools face the threat of permanent closure in 1996 because they are not considered by government to be viable educational institutions (Bray, 1987; Macaskill, 1991).

According to Tella (1995, p. 9), "Society is in a stage of development where the school relics engendered by industrial society are breaking down." As information and communication technologies combine and proliferate, it is not yet clear what will replace the traditional school.
Small rural schools in New Zealand are at the forefront of changes in educational organisation, as well as in pioneering new ways of teaching and learning. With the development of virtual classes, many small schools represent a collaborative system of organisation within the competitive framework of Tomorrow's Schools. The implications for the integrity of institutions that are no longer complete, autonomous teaching and learning systems have to be considered in policy terms. The participation of students in several schools simultaneously raises the question of whether they are part of a particular school or part of a network. Issues of classroom and school organisation in linked sites will require new management structures. At the present time, there is much goodwill in a number of New Zealand communities bound together by the common fear of school closure. As the information and communication technologies that are becoming increasingly common in rural "schools" in New Zealand expand and find places in the organisation of larger, more autonomous learning institutions, the question of exactly what a school is in the late twentieth century will have to be considered. At a policy level, a major question is likely to be whether governments should continue to fund schools as institutions or fund networked educational services which can be accessed by computers. The application of telecommunications to educational development in geographically isolated areas is a major issue in Australia (D'Cruz, 1990; Fasano, 1987) and the United States (Parker et al., 1989). The provision of education using new information and communication technologies is currently of interest to major political parties in New Zealand (Buckrell, 1992; New Zealand Labour Party, 1993; New Zealand National Party, 1993).

A technological issue that may emerge is whether schools should continue to invest in audiographic or video technologies, or consider the delivery potential of the Internet. At an educational level, the question of ownership of learning materials is likely to become a dominant issue, as expert teachers command larger classes nationwide and become, in effect, master teachers. Perhaps there will be a role for a new person in the electronic class of the not-too-distant future - the person who manages (rather then teaches) a room full of learners, as they are taught from several different sites simultaneously. Finally, the pedagogy of the smallest schools in New Zealand has become particularly relevant to the organisation of the virtual class. Perhaps the most urgent educational issue in the immediate future is to reconsider the policy of closing these small educational laboratories and dissipating the expertise contained within them. 


\section{References}

Bray, M. (1987). Are small schools the answer? Cost effective strategies for rural school provision. London: Commonwealth Secretariat Publications.

Buckrell, P. et al. (1992). The use of telecommunications technologies for the enhancement of educational services. Wellington: Department of the Prime Minister and Cabinet, Consultel Associates Limited.

Cross, W. \& Frankcombe, B. (1994). The small rural school, Vancouver: EduServ Inc.

D'Cruz, J. V. (1990). Technology and education: a study of policy and practice in rural schools (2nd ed.). Melbourne: Ministry of Education (Victoria).

Fasano, C., Hall, N. \& Cook, J. (1987). Information technology and the provision of educational services in rural New South Wales. Canberra: Unpublished interim case study report prepared for the Commonwealth Schools Commission.

Kynaslahti, H. and Salminen, J. (1995). Integration of remote classrooms: technical and local perspectives. In F. Nouwens (Ed.) Distance education - crossing frontiers. Rockhampton: Central Queensland University.

Macaskill, S. (1991). Report of the economic and educational viability of small schools review. Wellington: Ministry of Education.

Mander, T. (1993). Unpublished summary report of the Canterbury Area Schools' Association Distance Education Project (Casatech).

Mander, T. (1994). On-line delivery handbook. Christchurch: Christchurch College of Education.

Middleton, J. (1996, January). The battle for Donnelly's Crossing. New Zealand Listener, 27

New Zealand Labour Party. (1993). Education - our children, our future. Wellington: NZ Labour Party.

New Zealand National Party. (1993). Policy 1993 - the most highly skilled nation in the world. Wellington: NZ National Party.

Oliver, R. \& Reeves, T. (1993). Telematics in rural education. Perth: Intech Innovations.

Parker, E. B., Hudson, H. E., Dillman, D. A. \& Roscoe, A. D. (1989). Rural America in the information age: Telecommunications policy for rural development. Lanham, MD: The Aspen Institute and University Press of America.

Stevens, K. (1993a). The place of distance education networks in the vocational choice processes of geographically isolated students. In B. Scriven, R. Lundin \& Y. Ryan (Eds.) Distance education for the twenty-first century (pp. 170-174). Brisbane and Oslo: International Council for Distance Education and the Queensland University of Technology.

Stevens, K. J. \& Tate, O. (1993b). The changing nature of distance education in New Zealand: Some strategic implications. New Zealand Annual Review of Education, 3, 319-334.

Stevens, K. J. (1994). Some applications of distance education technologies and pedagogies in rural schools in New Zealand. Distance Education, 15(2), 318-326.

Stevens, K. J. (1995). The development of virtual classes in rural New Zealand communities - some teaching, learning and management issues. Paper presented at the New Zealand Association for Research in Education Conference, Palmerston North.

Telecom New Zealand. (1992). New Zealand telelearning network. Wellington: Telecom Corporation of New Zealand.

Tella, S. (1995). Virtual school in a networking learning environment. Helsinki: University of Helsinki, Department of Teacher Education.

Tiffin, J., Rajasingham, L. \& Pennings, A. (1992). The telelearning handbook. Wellington, Wordsworth Ltd.

\section{The author}

Dr Ken Stevens is a Senior Lecturer in the Department of Education at Victoria University of Wellington, where he specialises in rural, distance and vocational education. 